\title{
The influence of habitat type on the distribution of carabid beetles in traditionally managed "dehesa" ecosystems in NW Spain
}

\author{
Angela Taboada, D. Johan Kotze, José M. Salgado \& Reyes Tárrega
}

Taboada, A., Kotze, D. J., Salgado, J. M. \& Tárrega, R. 2006: The influence of habitat type on the distribution of carabid beetles in traditionally managed “dehesa" ecosystems in NW Spain. — Entomol. Fennica 17: 284-295.

We investigated the responses of carabid beetles to habitat type at the local scale in traditionally managed "dehesa" ecosystems in NW Spain. The beetles were sampled from two habitat types (central grassland and surrounding forested zone) of five "dehesa" ecosystems, from May to October 2004. A total of 4,374 carabid individuals and 55 species were captured using pitfall trapping. Most of the species were collected from both habitat types, probably due to open spaces created between old-growth trees in the forested zone. Differences in carabid assemblage composition were found mainly due to Harpalus species characteristic from the central grassland and a few forest specialist species exclusively found in the forested zone. The maintenance of the "dehesa" structure may be of importance for carabid species adapted to the variety of habitats created, and requires the continuation of traditional management practices.

A. Taboada and J. M. Salgado, Department of Animal Biology, University of León, Campus de Vegazana s/n, E-24071 León, Spain; E-mail: dbaatp @unileon.es

D. J. Kotze, Department of Biological and Environmental Sciences, P. O. Box 65 (Biocenter 3, Viikinkaari 1), FI-00014 University of Helsinki, Finland

R. Tárrega, Department of Ecology, Genetics and Microbiology, University of León, Campus de Vegazana s/n, E-24071 León, Spain

Received 12 December 2005, accepted 1 March 2006

\section{Introduction}

Historical land use and management practices, including forest burning and cutting to create agricultural land and pastures for livestock grazing, have altered and diversified the landscape in the Iberian Peninsula (Blanco et al. 1997, LuisCalabuig et al. 2000). In some cases, these traditional practices have transformed the forested land to create "dehesa" ecosystems, where the use of resources coexists with areas of high biological diversity (Gómez-Limón \& De Lucío Fernández 1999). A "dehesa" is an agro-forestry system with extensive grazing (sheep, goats, pigs and cattle); these multiple land-uses produce a landscape of high habitat heterogeneity (Blanco et al. 1997). The resulting anthropogenic mosaic (pasture, arable, woodland) produces a range of environmental conditions and niches that can enhance diversity (e.g., Pulido \& Díaz 1997, Martín \& López 2002).

The origin and evolution of the "dehesa" 


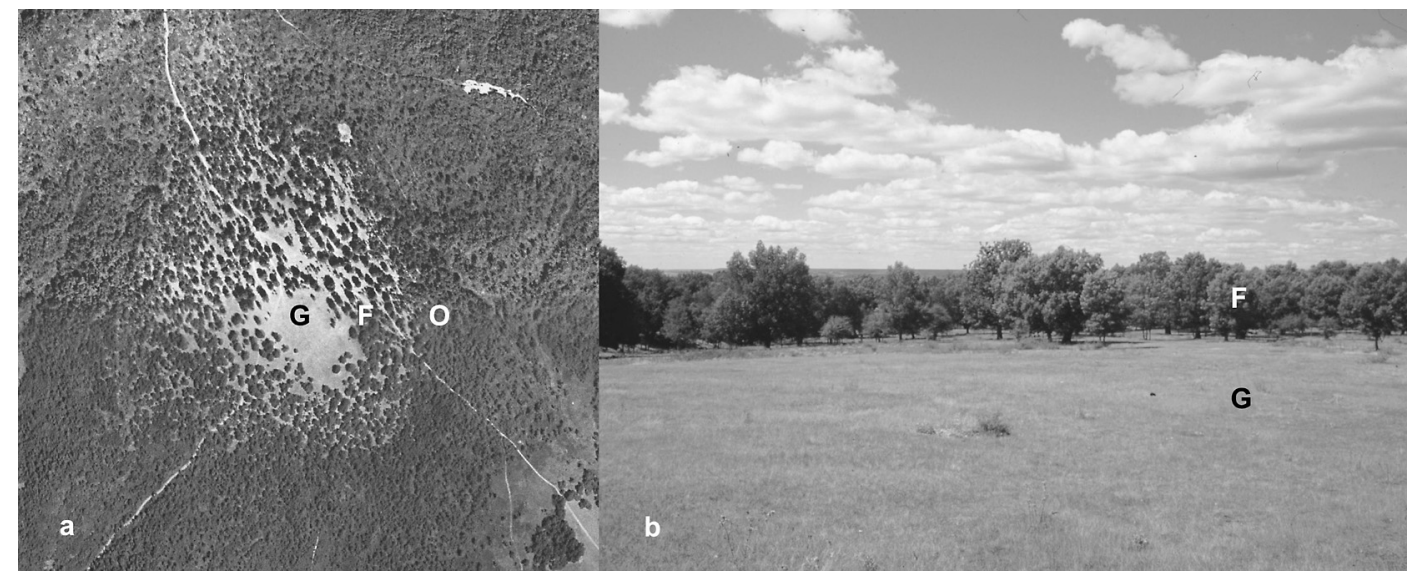

Figure 1. Composition of the dehesa ecosystem and its relation to the surrounding oak forest. a) Aerial view and b) detailed view. Habitat types: $\mathrm{G}=$ Central grassland, $\mathrm{F}=$ Forested zone, $\mathrm{O}=$ Surrounding oak forest.

landscape have been intrinsically related to transhumance pastoral systems for centuries (Blanco et al. 1997). Well-developed "dehesa" systems were established as a permanent feature of the Spanish landscape from the early Middle Ages, when clearing, thinning and ploughing of continuous oak forests were frequently performed. These management practices were developed in order to obtain regularly-spaced retained trees (between 30 and 60 trees per ha) and to enhance grassland growth among the trees (Blanco et al. 1997, Joffre et al. 1999, Pulido et al. 2001). Most contemporary "dehesa" ecosystems were created during the second half of the $19^{\text {th }}$ and the beginning of the $20^{\text {th }}$ centuries as a result of increased human densities (Pulido et al. 2001).

The degree of habitat diversity (i.e., differences in vegetation structure and composition) in a "dehesa" ecosystem is mainly dependent on management practices and different products obtained (e.g., forage, firewood, charcoal, acorn, cork, tannin). Basically, the vegetation structure of a "dehesa" is composed of two layers (Joffre et al. 1999): a savannah-like open tree layer with scattered mature oaks (mainly Quercus ilex and Q. suber) and a grass dominated layer (usually native annual herbs for grazing). The maintenance of this two-layered vegetation structure requires continuous management such as: a) control of shrub invasion by uprooting, clearing and ploughing, $b$ ) preservation of the old-growth tree layer by regular pruning to favour horizontal branches (to provide shade, browsing and acorn production), and c) the enhancement of tree regeneration by the planting of new seedlings (Blanco et al. 1997).

Here we investigate the responses of carabid beetles to habitat type (defined by the variability in the composition of the vegetation layer) at the local scale in traditionally managed "dehesa" ecosystems in NW Spain. We selected a Quercus pyrenaica "dehesa" system that typically consists of two main habitat types: 1) a central grassland area and 2) a surrounding forested zone characterised by scattered old-growth trees, which are maintained for livestock shelter and feeding purposes (Fig. 1).

We aim to determine if the carabid assemblages inhabiting the "dehesa" ecosystem differ between the central grassland and the surrounding forested zone despite their spatial proximity. We ask whether differences in environmental conditions due to tree development in the forested area influence the presence of carabid species according to their habitat preferences [see ReyesLópez et al. (2003) for ants]. Shade provided by the scattered trees in the forested zone increases microhabitat humidity, decreases temperature and contributes to leaf litter development and organic matter content (Joffre et al. 1999), leading also to modifications in the vegetation composition. These changes in environmental conditions may make the forested zone suitable for forest specialist species, even though these zones are not considered true forest ecosystems. Open hab- 
itat species are expected to thrive in the central grassland and generalist species are expected to be less influenced by the differences between the two habitat types.

\section{Material and methods}

\subsection{Study area and sampling method}

The study was conducted in NW Spain (42 $36^{\prime}-$ $\left.42^{\circ} 39^{\prime} \mathrm{N}, 4^{\circ} 58^{\prime}-5^{\circ} 05^{\prime} \mathrm{W}\right)$, in the Mediterranean Region 980-1,030 m a.s.1. We selected five Quercus pyrenaica "dehesa" ecosystems [Festuco heterophyllae-Querceto pyrenaicae sigmetum; Penas et al. (1995)] at least $1 \mathrm{~km}$ apart, surrounded by continuous oak forests and with a similar grazing intensity (sheep and goats). Each "dehesa" ecosystem included the two habitat types described above, and we sampled carabid beetles in five central grassland sites (size range 2.09-8.23 ha) and five surrounding forested sites (size range 11.50-24.64 ha).

Grazed and open central grasslands are dominated by a variety of herb species such as Aira caryophyllea, Cynosurus cristatus, Medicago lupulina, Ornithopus compressus, Trifolium arvense, T. campestre, T. glomeratum, T. pratense, T. strictum, and Vulpia bromoides (Díez et al. 1994, 1995). The surrounding forested zone is characterised by a more complex vegetation structure consisting of several layers: oak trees, oak saplings, shrubs and annual and perennial herbs (Table 1).

Vegetation sampling in these forested zones were carried out in June-July 2004: (a) understory vegetation cover (shrubs, herbs and saplings) was visually estimated in 20 systematically placed $1 \mathrm{~m} \times 1 \mathrm{~m}$ quadrats per site; (b) oak tree characteristics (perimeter, height, canopy diameter and distance between trees) were measured from 40 trees per site.

We used plastic pitfall traps (depth $86 \mathrm{~mm}$, diameter $60 \mathrm{~mm}$ ) covered by $10 \mathrm{~cm} \times 10 \mathrm{~cm}$ roofs and partly filled with $25 \%$ propylene glycol to collect the beetles. Pitfall catches reflect carabid activity-density (e.g., Thomas 1998) that will be referred to here as abundance or number of individuals. Five sampling points were placed in each of the ten sites. Each sampling point consisted of

Table 1. Structural characteristics of the vegetation at the five forested zones. Dominant herb (annual and perennial herbs) and scarce $(<5 \%$ cover) shrub species at each zone are given. Oak saplings $(<1 \mathrm{~m}$ height) are indicated when cover was greater than $2 \%$. Mean \pm Standard Deviation distance between oak trees, tree height, perimeter and canopy diameter are also given.

\begin{tabular}{|c|c|c|c|c|c|c|c|}
\hline & Annual herbs & Perennial herbs & Shrubs & $\begin{array}{l}\text { Mean } \pm S D \\
\text { tree dist. } \\
(\mathrm{m})\end{array}$ & $\begin{array}{l}\text { Mean } \pm S D \\
\text { tree ht. } \\
(\mathrm{m})\end{array}$ & $\begin{array}{l}\text { Mean } \pm S D \\
\text { tree perim. } \\
(\mathrm{cm})\end{array}$ & $\begin{array}{l}\text { Mean } \pm S D \\
\text { canopy } \\
\text { diam. }(m)\end{array}$ \\
\hline 1 & $\begin{array}{l}\text { Aira caryophyllea } \\
\text { Cynorosus echinatus } \\
\text { Tuberaria guttata }\end{array}$ & $\begin{array}{l}\text { Agrostis capillaris } \\
\text { Festuca rubra } \\
\text { Plantago lanceolata }\end{array}$ & Crataegus monogyna & $7.70 \pm 3.76$ & $8.46 \pm 4.42$ & $73.33 \pm 71.47$ & $6.49 \pm 4.66$ \\
\hline 2 & Tuberaria guttata & $\begin{array}{l}\text { Agrostis capillaris } \\
\text { Carex muricata } \\
\text { Festuca rubra }\end{array}$ & $\begin{array}{l}\text { Erica cinerea } \\
\text { Halimium umbellatum } \\
\text { Oak saplings }\end{array}$ & $7.65 \pm 5.32$ & $11.03 \pm 4.14$ & $123.40 \pm 112.32$ & $7.45 \pm 4.97$ \\
\hline 3 & $\begin{array}{l}\text { Aira caryophyllea } \\
\text { Cynosurus echinatus } \\
\text { Tuberaria guttata } \\
\text { Vulpia bromoides }\end{array}$ & Agrostis capillaris & $\begin{array}{l}\text { Halimium umbellatum } \\
\text { Oak saplings }\end{array}$ & $9.66 \pm 5.17$ & $10.20 \pm 4.70$ & $98.68 \pm 102.69$ & $6.83 \pm 4.50$ \\
\hline 4 & $\begin{array}{l}\text { Aira caryophyllea } \\
\text { Tuberaria guttata } \\
\text { Vulpia bromoides }\end{array}$ & $\begin{array}{l}\text { Agrostis capillaris } \\
\text { Hieracium castellanum } \\
\text { Hieracium gr. pilosella } \\
\text { Plantago lanceolata }\end{array}$ & Thymus serpyllum & $7.18 \pm 4.34$ & $10.18 \pm 4.96$ & $87.80 \pm 91.43$ & $6.08 \pm 4.27$ \\
\hline 5 & $\begin{array}{l}\text { Aira caryophyllea } \\
\text { Trifolium campestre }\end{array}$ & $\begin{array}{l}\text { Agrostis capillaries } \\
\text { Carex muricata } \\
\text { Festuca rubra } \\
\text { Hieracium gr. pilosella }\end{array}$ & $\begin{array}{l}\text { Calluna vulgaris } \\
\text { Erica umbellate } \\
\text { Lithodora diffusa } \\
\text { Thymus serpyllum } \\
\text { Oak saplings }\end{array}$ & $5.53 \pm 3.13$ & $13.88 \pm 2.10$ & $86.20 \pm 48.26$ & $6.64 \pm 3.03$ \\
\hline
\end{tabular}


Table 2. Generalised linear model results. $d f=$ degrees of freedom. Residual Deviance is the amount of variation not explained by the models; $p$ values in parentheses (boldface if $p<0.05 ; \chi^{2}$ distribution). The Central grassland (Grassl.) coefficients are the basic intercepts of the models; Forest $=$ forested zone. Theta (with SE) is the aggregation value (for negative binomial models only) with lower values indicating a higher degree of aggregation.

\begin{tabular}{|c|c|c|c|c|c|c|c|c|c|}
\hline & \multirow[b]{2}{*}{ Null Dev. } & \multicolumn{3}{|c|}{ Resid. Dev. $(p)$} & \multicolumn{4}{|c|}{ Coeff. } & \multirow[b]{2}{*}{ Theta (SE) } \\
\hline & & Size & Ants & Habitat type & Size & Ants & Grassl. & Forest & \\
\hline Residual df & 9 & 8 & 7 & 6 & & & & & \\
\hline Abundance & 272.79 & $264.40(\mathbf{0 . 0 0 4})$ & $263.56(0.361)$ & $16.91(<0.001)$ & -0.051 & $9.49 \times 10^{-5}$ & -1.248 & 0.870 & \\
\hline Rarefied Richness & 4.26 & $4.25(0.902)$ & $3.79(0.497)$ & $3.79(0.976)$ & 0.009 & $1.85 \times 10^{-4}$ & 2.675 & -0.009 & \\
\hline Calathus fuscipes & 14.56 & $14.17(0.536)$ & $14.17(0.946)$ & $10.80(0.067)$ & -0.039 & $3.94 \times 10^{-4}$ & -3.419 & 1.409 & 86) \\
\hline Carabus amplipennis & 44.85 & $11.52(<0.001)$ & $9.35(0.140)$ & $7.44(0.167)$ & 0.093 & $-1.75 \times 10^{-3}$ & -7.708 & 1.896 & 3.0 \\
\hline Harpalus distinguendus & s 58.67 & $16.61(<0.001)$ & $14.25(0.124)$ & $12.08(0.141)$ & -0.207 & $-9.00 \times 10^{-4}$ & -0.791 & -1.283 & $2.29(1.34)$ \\
\hline Harpalus ebeninus & 25.40 & $24.85(0.459)$ & $18.54(\mathbf{0 . 0 1 2})$ & $7.56(<0.001)$ & -0.119 & $5.91 \times 10^{-3}$ & -13.350 & 5.977 & $0.99(0.66)$ \\
\hline Harpalus rufipalpis & 29.81 & $15.01(<0.001)$ & $11.39(0.057)$ & $8.56(0.093)$ & -0.317 & $1.92 \times 10^{-3}$ & -5.068 & 2.165 & $1.30(0.70)$ \\
\hline Harpalus serripes & 17.70 & $11.15(\mathbf{0 . 0 1 1})$ & $8.64(0.113)$ & $8.44(0.652)$ & 0.070 & $5.17 \times 10^{-3}$ & -10.640 & -1.408 & $0.44(0.26)$ \\
\hline Nebria salina & 18.54 & $16.61(0.164)$ & $12.86(0.053)$ & $10.09(0.096)$ & -0.114 & $-9.17 \times 10^{-4}$ & -4.407 & 2.107 & $1.69(0.88)$ \\
\hline Poecilus kugelanni & 35.23 & $28.33(0.009)$ & $20.21(\mathbf{0 . 0 0 4 )}$ & $12.76(\mathbf{0 . 0 0 6})$ & 0.057 & $1.87 \times 10^{-3}$ & -7.920 & 2.063 & $2.60(1.69)$ \\
\hline Steropus gallega & 25.26 & $20.22(\mathbf{0 . 0 2 5})$ & $14.99(\mathbf{0 . 0 2 2})$ & $12.68(0.128)$ & -0.095 & $-2.53 \times 10^{-3}$ & -3.567 & 1.505 & $1.54(1.24)$ \\
\hline Steropus globosus & 22.44 & $22.17(0.603)$ & $12.53(\mathbf{0 . 0 0 2})$ & $10.57(0.161)$ & 0.060 & $1.95 \times 10^{-3}$ & -5.782 & 0.771 & $3.71(1.76)$ \\
\hline Syntomus foveatus & 25.31 & $13.30(<0.001)$ & $13.14(0.690)$ & $11.21(0.165)$ & 0.005 & $4.69 \times 10^{-4}$ & -4.412 & -2.550 & $1.11(0.58)$ \\
\hline Trechus obtusus & 16.13 & $12.91(0.073)$ & $12.91(0.939)$ & $11.96(0.329)$ & -0.018 & $-2.22 \times 10^{-4}$ & -5.489 & 1.621 & $0.92(0.50)$ \\
\hline Trechus quadristriatus & 23.49 & $15.60(\mathbf{0 . 0 0 5})$ & $15.10(0.476)$ & $12.04(0.081)$ & -0.034 & $-2.46 \times 10^{-4}$ & -6.256 & 2.911 & $0.97(0.61)$ \\
\hline Zabrus silphoides & 26.11 & $12.64(<0.001)$ & $11.04(0.206)$ & $10.54(0.478)$ & -0.173 & $1.10 \times 10^{-3}$ & -4.973 & 0.786 & $1.66(0.99)$ \\
\hline Generalist group & 27.65 & $22.31(\mathbf{0 . 0 2 1})$ & $16.89(\mathbf{0 . 0 2 0})$ & $10.63(\mathbf{0 . 0 1 2})$ & 0.193 & $2.00 \times 10^{-3}$ & -7.412 & -3.274 & $2.43(1.46)$ \\
\hline Open habitat group & 13.18 & $11.23(0.162)$ & $10.37(0.354)$ & $10.37(0.972)$ & -0.006 & $7.55 \times 10^{-4}$ & -4.635 & -0.033 & $2.91(1.39)$ \\
\hline
\end{tabular}

three traps 50-200 cm apart (i.e., 15 traps per site, 150 traps in total). Sampling points were at least $30 \mathrm{~m}$ apart and as far as possible from site edges. Beetles were collected continuously from 28 May to 4 October in 2004, and traps were emptied every 20-25 days. Beetles were identified using standard keys (Jeannel 1941-1942, Lindroth 1974, Trautner \& Geigenmüller 1987), and follow the nomenclature in Serrano (2003). We counted the number of ants (Formicidae) collected in the traps due to high abundances obtained.

\subsection{Data analysis}

We pooled the carabid catches of each site and for the whole trapping period, and classified the species as forest specialists, generalists or open habitat species, according to the literature (Jeannel 1941-1942, Lindroth 1974, Vázquez 1990, Campos 2003, Ortuño \& Marcos 2003 \& Peláez 2004; see Appendix).
Generalised linear models (GLM) were used to test for differences in carabid abundance and species richness between the two habitat types. Species representing at least 50 individuals and collected from at least five of the ten sites were analysed individually. The remaining species were pooled into groups according to the above mentioned habitat classification in order to include them into the analysis. Calathus granatensis and the forest specialist group were not tested, as they were clearly associated with the forested zone. The response variables in the models were number of individuals (overall and for individual species) and overall number of species (i.e., species richness). Abundance data were modelled following a negative binomial error distribution (White \& Bennetts 1996) unless specified otherwise (see Table 2), and species richness data were modelled following a Poisson error distribution. The predictor variable was habitat type (central grassland and forested zone). Site size and mean ant abundance per site were included into the models as exploratory variables. Ants 
were included into the models because in previous studies potential competitor groups explained a large amount of the variability found in the carabid assemblages and individual species (Taboada et al. unpubl.). As a result of management practices and the "dehesa" habitat configuration, central grasslands are unavoidably smaller than surrounding forested zones and, consequently, size and habitat type were statistically confounded in the models (Pearson's correlation: $r=0.75, \mathrm{df}=8, p=0.001)$. Therefore, the predicted values obtained (see Figs. 2 and 3) were based on: a) the mean size of each habitat type (i.e., 4.22 ha for central grasslands and 17.65 ha for forested zones) in order to get a more realistic prediction for each habitat type independently of size, and on b) the overall mean size (i.e., the mean size of the ten sites, 10.94 ha, which is located outside the true size ranges of both habitat types) in order to obtain a valid (although less realistic) comparison between habitat types by taking size into account.

We performed a Detrended Correspondence Analysis (DCA) to correlate carabid species and sites (Jongman et al. 1995), assuming a unimodal (Gaussian) response of carabid beetle abundances to the environment. Species with at least 15 individuals ( 26 species) were included in this analysis, avoiding the inclusion of scarce species according to our dataset.

Unequal trapping effort (19\% trap loss) was corrected by including the number of days the traps per site were active as an offset term in the abundance models, and by rarefying species richness data to 200 individuals. Abundance data for the DCA analysis were standardised to 100 trapping days. Data analyses were carried out with the $\mathrm{R}$ statistical package (R Development Core Team 2005).

\section{Results}

We collected 4,374 carabid individuals and 55 species (Appendix). Overall carabid abundance was statistically significantly higher in the forested zone (Table 2, Fig. 2a). Rarefied species richness did not differ significantly between the two habitat types (Table 2, Fig. 2b).

Both habitat types supported mainly open
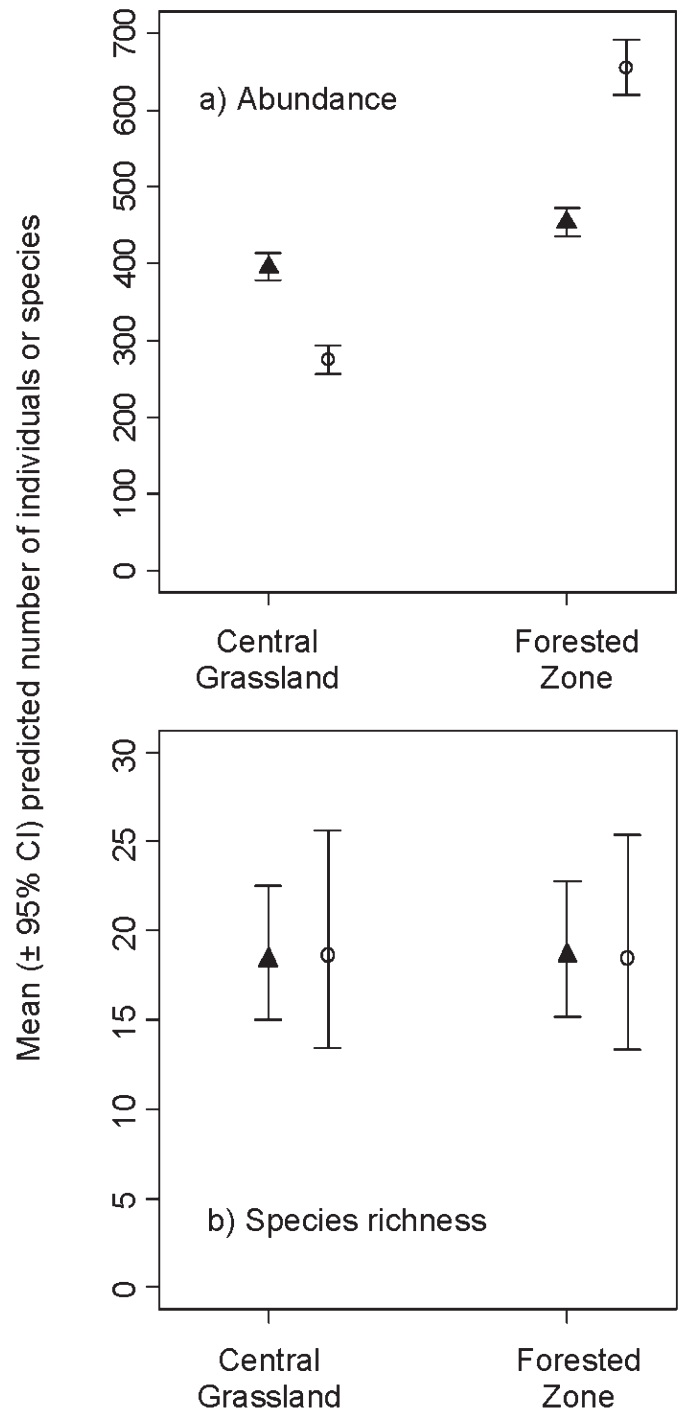

Figure 2. Mean ( $\pm 95 \%$ Confidence Interval) predicted number of carabid individuals and species at the two habitat types. Predictions were obtained with: the mean size of each habitat type $(\boldsymbol{\Delta})$ and the overall mean size $(O)$; see text. Predicted values for abundance were standardised to the mean number of active trapping days per site (i.e., 1,543 days). Predicted values for species richness were obtained after rarefaction to 200 individuals.

habitat $(57.8 \%$ and $48.6 \%$ in central grasslands and forested zones, respectively) and generalist species ( $42.2 \%$ and $37.9 \%$, respectively). No forest specialist species were captured from the central grasslands, but $13.5 \%$ of the species captured exclusively from the forested zones were forest 
Figure 3. Mean $( \pm 95 \%$ $\mathrm{Cl}$ ) predicted number of individuals of the most representative species at the two habitat types. Predictions were obtained with: the mean size of each habitat type $(\mathbf{\Delta})$ and the overall mean size (O). Predicted values were standardised to the mean number of active trapping days per site (i.e., 1,543 days).
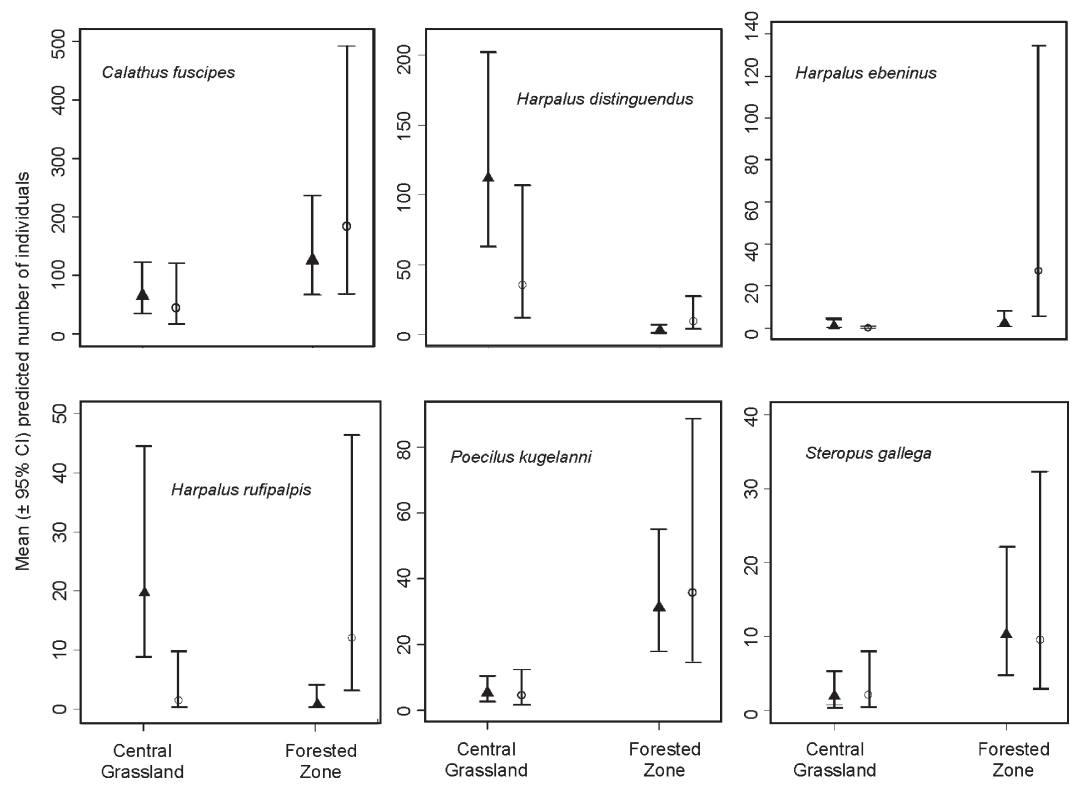

specialists, including Calathus rotundicollis, $\mathrm{Ca}$ losoma inquisitor, Carabus lusitanicus and Notiophilus biguttatus (Appendix). Calathus granatensis, a generalist species according to the literature, was also exclusively collected from the forested zones.

The most abundant species were collected from both central grasslands and forested zones: Calathus fuscipes (1,071 individuals, $24.5 \%$ of the total catch), Steropus globosus (769 individuals, 17.6\%) and Harpalus distinguendus (612 individuals, 14\%), all generalist species. Only two (Harpalus ebeninus and Poecilus kugelanni) of the 14 species tested, responded statistically significantly to habitat type (i.e., responded positively to the forested zone, Table 2). Nine of the 14 species tested responded statistically significantly to the size of the studied sites, and the number of ants was a significant predictor of the abundance of four beetles tested (Table 2).

In general, habitat size had a negligible effect on the species responses to habitat type as most of the species tested responded in the same direction when we compared the predicted values obtained from the overall mean size to the predicted values obtained from the mean size of each habitat type (Fig. 3).

We identified three types of responses of the species to habitat type: (a) most of the species responded either as generalists or are mainly asso- ciated to the forested zone, independently of size (for example, Calathus fuscipes, Harpalus ebeninus, Poecilus kugelanni and Steropus gallega; Table 2, Fig. 3); (b) two species responded as generalists in the statistical sense (i.e., no statistically significant difference between the two habitat types) and as open habitat species in the ecological sense (Harpalus distinguendus and Harpalus serripes; Table 2, Fig. 3); and (c) two species responded highly negatively to habitat size (Harpalus rufipalpis and Zabrus silphoides; Table 2, Fig. 3).

In addition, species in the open habitat group (24 species) were not statistically significantly associated with either of the habitat types, while the generalist group (11 species) was statistically significantly associated with the central grasslands (Table 2). The forest specialist group (five species) responded to habitat type as expected (not tested as it was clearly associated with the forested zone).

Results from the DCA analysis (Fig. 4) showed that the carabid assemblage composition of the two habitat types clearly differed, mainly due to the presence of Harpalus species (open and generalist species) in the central grasslands, and forest specialist species (e.g., Calathus rotundicollis and Calosoma inquisitor) and other abundantly collected species at the forested zones (e.g., Poecilus kugelanni). 


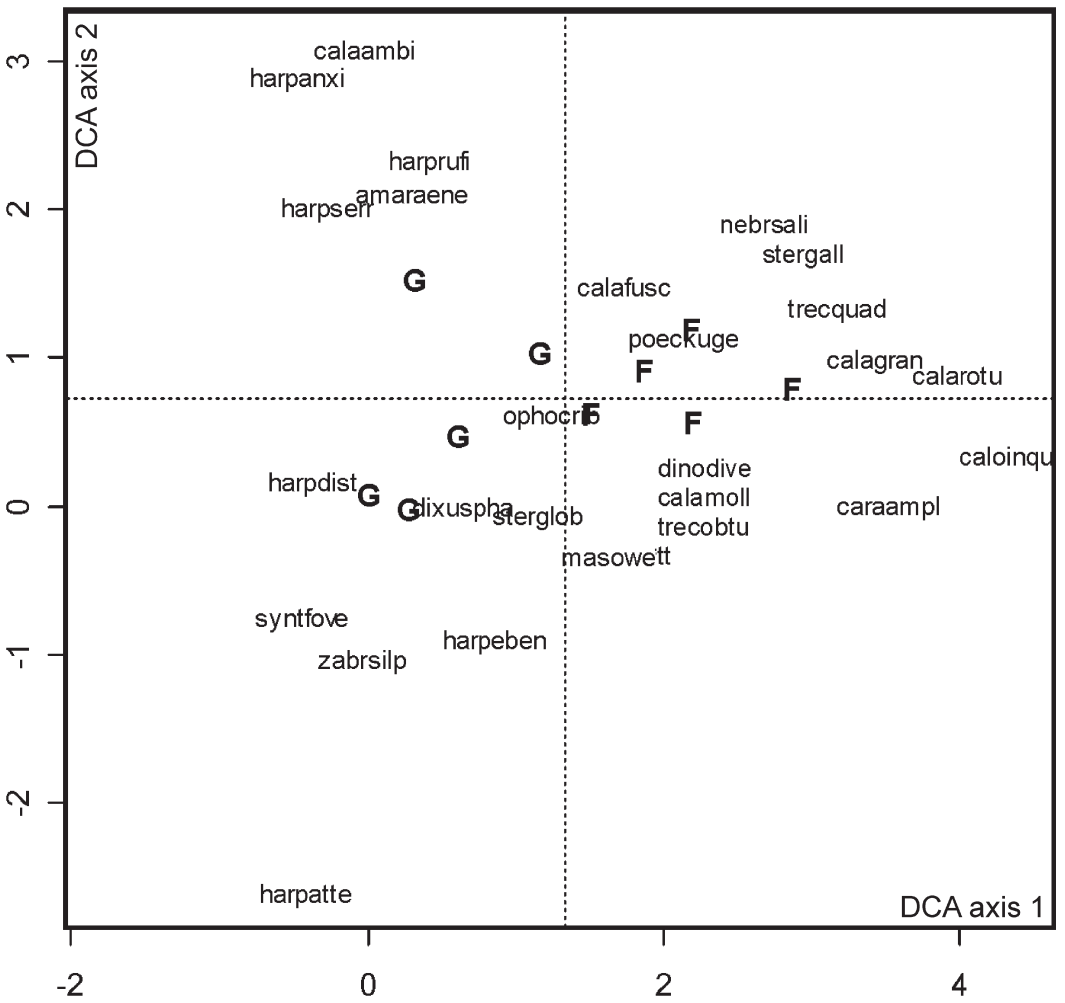

Figure 4. Detrended Correspondence Analysis (eigenvalues and axis lengths: 0.52 and 2.86 SD for axis 1 , and 0.21 and 1.54 SD for axis 2, respectively) for carabid species and sites. Habitat types: $\mathrm{G}=$ Central grassland, $\mathrm{F}=$ Forested zone. Carabid names are a combination of 4 (genus name) by 4 (species name) letters. For example, calaambi $=$ Calathus ambiguus.

\section{Discussion}

Even though the two habitat types sampled here were quite different in terms of vegetation structure, we showed that they were quite similar regarding to the carabid beetles - most species did not respond to habitat type (i.e., were collected from both central grasslands and forested zones). Some of these species were collected from the forested zones but were mainly characteristic of the open central grasslands, such as species of the genus Harpalus, as shown in the DCA analysis. These species may prefer the environmental conditions that characterise the central grassland, like higher temperature and lower moisture, but may also occasionally move into the surrounding forested zone. Human-created spaces between oldgrowth trees in the forested zone may allow these species to move from and to the central grassland (Koivula \& Niemelä 2003). Besides, as temperature has a significant effect on carabid beetle movement (Raworth \& Choi 2001), it may also have influenced pitfall catches in the central grasslands (i.e., higher temperatures imply higher movement rates and consequently a higher activity-density measure from pitfall traps).

On the other hand, some species were more abundantly found in the forested zone, but cannot be considered as true forest specialist species. These species may be associated to specific environmental conditions created under the oak trees (see Reyes-López et al. 2003). For example, Poecilus kugelanni was abundantly found in meadow areas characterised by non grazed tall grasses (Taboada et al. unpubl.) that are also characteristic of the immediate oak tree surroundings in the forested zone.

Differences between the two habitat types were also found in terms of higher overall abundance and carabid assemblage composition, mainly due to high numbers of Harpalus species collected from the central grasslands and due to species collected exclusively from the forested zones, as reflected in the DCA analysis. The maintenance of the forested zone characterised by mature oak trees, with great canopy cover, perimeter and height, positively influenced the presence of a few forest specialist species. These spe- 
cies may move from the well-developed surrounding oak forest (see Taboada et al. 2004) to the forested zone due to shade and humidity provided by tree development, and probably the more diverse microhabitats created by leaf litter accumulation (Koivula et al. 1999). Some species, such as Carabus lusitanicus and Notiophilus biguttatus, were found in low numbers in the surrounding forested zone, but in case of the rare Calosoma inquisitor the forested zone of the "dehesa" probably provides a suitable habitat.

Our results further suggest that ants are a significant predictor of the distribution of four carabid species tested. We found either positive or negative responses of carabids to ants. Although ants appear to affect carabid abundance and species richness negatively (Lövei \& Sunderland 1996, Hawes et al. 2002), individual species responded differently to the presence of wood ants, depending on their daily activity patterns [e.g., in spruce boreal forests; Koivula et al. (1999, 2002)] and their abilities to avoid direct encounters and predation by ants [in mixed pine-birch forests; Reznikova \& Dorosheva (2004)] or in their ability to produce defensive chemicals [e.g., formic acid; Will et al. (2000)].

In terms of carabid beetle assemblages, the forested zones of the "dehesas" are not that different from the central grasslands and cannot be considered as true forest ecosystems. Furthermore, main differences in carabid beetles are expected between the open "dehesa" ecosystem (i.e., central grassland and surrounding forested zone together) and the closed oak forest, a hypothesis that will be addressed in the future. It may well be that the "dehesa" carabid beetles constitute a unique assemblage that depends on habitat diversity of the "dehesa" ecosystem, making it worthy of conservation efforts.

The long-term maintenance of the "dehesa" landscape strongly depends upon varied local uses (Gómez-Limón \& De Lucío Fernández 1999). Over the last 60 years, great changes in the Mediterranean rural landscape, together with changes in the agriculture policies of the European Union, resulted in either the intensification of agricultural and livestock farming or the abandonment of traditional and non-competitive land uses, leading to the disappearance of "dehesa" ecosystems. Transformation of "dehesas" into simplified agricultural lands in case of intensification, or into closed oak forested lands (i.e., due to invasion by young trees and shrubs from the surroundings) in case of abandonment, have lead to the alteration of the vegetation composition and structure in these ecosystems (Díez et al. 1991, Gómez-Limón \& De Lucío Fernández 1999, Plieninger et al. 2003, Peco et al. 2005). This loss in habitat diversity in the "dehesa" ecosystem may affect the fauna, and especially those specialist species adapted to habitat heterogeneity (Niemelä et al. 1996, Stoate et al. 2001). Indeed, in case of carabid beetles, the assemblage composition is expected to vary along landscape transformations due to land use intensification (Fournier \& Loreau 1999, Vanbergen et al. 2005) and abandonment (Burel \& Baudry 1995, Purtauf et al. 2004).

Preserving the characteristic habitat diversity of "dehesas" in NW Spain means that specific and traditional practices are needed, such as shrub control (by cutting or grazing by goats), tree care (cutting branches, removing old trees, sanitary care, planting of new trees) and livestock management (i.e., balanced feeding in the whole area) (Blanco et al. 1997, Plieninger et al. 2003). Ultimately, the preservation of "dehesas" requires that conservation policies integrate participatory planning approaches that consider the motivations of local people (landowners and land-users) and the appreciation of "dehesa" incomes (Plieninger et al. 2004) as most "dehesas" are privately owned or local renting systems.

Acknowledgements. We thank L. Calvo and H. Robles for collaboration, S. Lehvävirta for useful comments and B. O'Hara for statistical advice. A. Vanbergen and an anonymous reviewer improved the manuscript considerably. Landscape measurements were carried out with SIGPAC (http://sigpac.mapa.es/fega/visor). We thank the Servicio Territorial de Medio Ambiente de la Junta de Castilla y León who granted access to the forests and several forest guards for collaboration. The study was supported by Ministerio de Ciencia y Tecnología (project reference REN2003-05432/GLO). A. Taboada was financed by Junta de Castilla y León, Spain and CIMO, Finland. 


\section{References}

Blanco, E., Casado, M. A., Costa, M., Escribano, R., García, M., Génova, M., Gómez, A., Gómez, F., Moreno, J. C., Morla, C., Regato, P. \& Sáinz, H. 1997: Los bosques ibéricos. Una interpretación geobotánica. — Editorial Planeta, Barcelona, Spain. 572 pp. [In Spanish.]

Burel, F. \& Baudry, J. 1995: Species biodiversity in changing agricultural landscapes: A case study in the Pays d'Auge, France. - Agric. Ecosyst. Environ. 55: 193200.

Campos, A. M. 2003: Estudio de los Carabidae (Coleoptera) de Galicia. - PhD thesis, Univ. of Santiago de Compostela, Spain. 660 pp. [In Spanish.]

Díez, C., Luis, E., Tárrega, R. \& Valbuena, L. 1991: Degradation process in traditional systems of sylvopastoral management in dehesa systems dominated by Quercus pyrenaica. — Proceedings of the "IV Congrès International des Terres de Parcours", pp. 107109.

Díez, C., Luis, E., Tárrega, R. \& Alonso, P. 1994: Estudio de las leguminosas en dehesas de roble de Quercus pyrenaica y su relación con las características edáficas. - Proceedings of the "XXXIV Reunión Científica de la Sociedad Española para el Estudio de los Pastos (S.E.E.P.)”, pp. 71-77. [In Spanish.]

Díez, C., Luis, E., Tárrega, R. \& Alonso, P. 1995: Estudio de las gramíneas en dehesas de roble de Quercus pyrenaica y su relación con las características edáficas. - Proceedings of the "XXXV Reunión Científica de la Sociedad Española para el Estudio de los Pastos (S.E.E.P.)", pp. 43-47. [In Spanish.]

Fournier, E. \& Loreau, M. 1999: Effects of newly planted hedges on ground-beetle diversity (Coleoptera, Carabidae) in an agricultural landscape. - Ecography 22: 87-97.

Gómez-Limón, J. \& De Lucío Fernández, J. V. 1999: Changes in use and landscape preferences on the agricultural-livestock landscapes of the central Iberian Peninsula (Madrid, Spain). - Landsc. Urban Plan. 44: $165-175$.

Hawes, C., Stewart, A. J. A. \& Evans, H. F. 2002: The impact of wood ants (Formica rufa) on the distribution and abundance of ground beetles (Coleoptera: Carabidae) in a Scots pine plantation. — Oecologia 131:612619.

Jeannel, R. 1941-1942: Coléoptères Carabiques. Faune de France, vol. 39 and 40. - Lechevalier, Paris. 1173 pp.

Joffre, R., Rambal, S. \& Ratte, J. P. 1999: The dehesa system of southern Spain and Portugal as a natural ecosystem mimic. - Agrofor. Syst. 45: 57-79.

Jongman, R. H. G., Ter Braak, C. J. F. \& Van Tongeren, O. F. R. 1995: Data Analysis in Community and Landscape Ecology. - Cambridge University Press, Cambridge. 299 pp.

Koivula, M., Kukkonen, J. \& Niemelä, J. 2002: Boreal carabid-beetle (Coleoptera, Carabidae) assemblages along the clear-cut originated succession gradient. -
Biodivers. Conserv. 11:1269-1288.

Koivula, M. \& Niemelä, J. 2003: Gap felling as a forest harvesting method in boreal forests: responses of carabid beetles (Coleoptera, Carabidae). - Ecography 26:179-187.

Koivula, M., Punttila, P., Haila, Y. \& Niemelä, J. 1999: Leaf litter and the small-scale distribution of carabid beetles (Coleoptera, Carabidae) in the boreal forest. Ecography 22: 424-435.

Lindroth, C. H. 1974: Handbooks for the Identification of British Insects. Coleoptera, Carabidae. - Royal Entomological Society, London. 148 pp.

Lövei, G. L. \& Sunderland, K. D. 1996: Ecology and behaviour of ground beetles (Coleoptera: Carabidae). Annu. Rev. Entomol. 41:231-256.

Luis-Calabuig, E., Tárrega, R., Calvo, L., Marcos, E. \& Valbuena, L. 2000: History of landscape changes in Northwest Spain according to land use and management. - In: Trabaud, L. (ed.), Life and Environment in the Mediterranean: 43-86. Wit Press, Southampton, U. K.

Martín, J. \& López, P. 2002: The effect of Mediterranean dehesa management on lizard distribution and conservation. - Biol. Conserv. 108: 213-219.

Niemelä, J, Haila Y. \& Punttila, P. 1996: The importance of small-scale heterogeneity in boreal forests: variation in diversity in forest-floor invertebrates across the succession gradient. - Ecography 19: 352-368.

Ortuño, V. M. \& Marcos, J. M. 2003: Los Caraboidea (Insecta: Coleoptera) de la comunidad autónoma del País Vasco. Tomo I. - Servicio Central de Publicaciones del Gobierno Vasco, Spain. 573 pp. [In Spanish.]

Peco, B., De Pablos, I., Traba, J. \& Levassor, C. 2005: The effect of grazing abandonment on species composition and functional traits: the case of dehesa grasslands. Basic Appl. Ecol. 6: 175-183.

Peláez, M. C. 2004: Estudio faunístico, ecológico y biogeográfico de los Carabidae (Coleoptera) del macizo del Sueve (Asturias, España). - PhD thesis, Univ. of León, Spain. 893 pp. [In Spanish.]

Penas, A., García, M. E. \& Herrero, L. 1995: Series de vegetación. Atlas del medio natural de la provincia de León. - Instituto Tecnológico Geominero de España y Diputación de León, León, Spain. 104 pp. [In Spanish.]

Plieninger, T., Pulido, F. J. \& Konold, W. 2003: Effects of land-use history on size structure of holm oak stands in Spanish dehesas: implications for conservation and restoration. - Environ. Conserv. 30: 61-70.

Plieninger, T., Modolell y Mainou, J. \& Konold, W. 2004: Land manager attitudes toward management, regeneration and conservation of Spanish holm oak savannas (dehesas). - Landsc. Urban Plan. 66: 185-198.

Pulido, F. J. \& Díaz, M. 1997: Linking individual foraging behaviour and population spatial distribution in patchy environments: a field example with Mediterranean blue tits. - Oecologia 111: 434-442.

Pulido, F. J., Díaz, M. \& Hidalgo De Trucios, S. J. 2001: Size structure and regeneration of Spanish holm oak 
Quercus ilex forests and dehesas: effects of agroforestry use on their long-term sustainability. - For. Ecol. Manage. 146: 1-13.

Purtauf, T., Dauber, J. \& Wolters, V. 2004: Carabid communities in the spatio-temporal mosaic of a rural landscape. - Landsc. Urban Plan. 67: 185-193.

R Development Core Team 2005: R: A language and environment for statistical computing. - R Foundation for Statistical Computing, Vienna, Austria. ISBN 3900051-07-0; URL http://www.R-project.org

Raworth, D. A. \& Choi, M-Y. 2001: Determining numbers of active carabid beetles per unit area from pitfall-trap data. - Entomol. Exp. Appl. 98: 95-108.

Reyes-López, J., Ruiz, N. \& Fernández-Haeger, J. 2003: Community structure of ground-ants: the role of single trees in a Mediterranean pastureland. - Acta Oecol. 24: 195-202.

Reznikova, Z. \& Dorosheva, H. 2004: Impacts of red wood ants Formica polyctena on the spatial distribution and behavioural patterns of ground beetles (Carabidae). Pedobiologia 48:15-21.

Serrano, J. 2003: Catálogo de los Carabidae (Coleoptera) de la Península Ibérica. - Monografías de la Sociedad Entomológica Aragonesa vol. 9, Zaragoza, Spain. 130 pp. [In Spanish.]

Stoate, C., Boatman, N. D., Borralho, R. J., Rio Carvalho, C., De Snoo, G. R. \& Eden, P. 2001: Ecological impacts of arable intensification in Europe. - J. Envi- ron. Manage. 63: 337-365.

Taboada, A., Kotze, D. J. \& Salgado, J. M. 2004: Carabid beetle occurrence at the edges of oak and beech forests in NW Spain. - Eur. J. Entomol. 101: 555-563.

Thomas, C. F. G., Parkinson, L. \& Marshall, E. J. P. 1998: Isolating the components of activity-density for the carabid beetle Pterostichus melanarius in farmland. Oecologia 116: 103-112.

Trautner, J. \& Geigenmüller, K. 1987: Tiger Beetles, Ground Beetles: Illustrated Key to the Cicindelidae and Carabidae of Europe. - Margraf, Germany. 488 pp.

Vanbergen, A. J., Woodcock, B. A., Watt, A. D. \& Niemelä, J. 2005: Effect of land-use heterogeneity on carabid communities at the landscape scale. - Ecography 28: 3-16.

Vázquez, M. G. 1990: Estudio faunístico, biogeográfico y ecológico de los Caraboidea (Coleoptera) entre las cuencas de los ríos Bernesga, Torío y Porma (León, España). — PhD thesis, Univ. of León, Spain. 455 pp. [In Spanish.]

White, G. C. \& Bennetts, R. E. 1996: Analysis of frequency count data using the negative binomial distribution. - Ecology 77: 2549-2557.

Will, K. W., Attygalle, A. B. \& Herath, K. 2000: New defensive chemical data for ground beetles (Coleoptera: Carabidae): interpretations in a phylogenetic framework. - Biol. J. Linnean Soc. 71: 459-481. 
Appendix. Carabid beetles collected in the five central grasslands and the five forested zones. Wings $(\mathrm{W})=$ wings morphology ( $b=$ brachypterous, micropterous or flightless, i.e. unable to fly; $m=$ macropterous; $D=$ dimorphic). Habitat $(H)=$ habitat association of the species ( $F=$ forest, $G=$ generalist and $O=$ open habitat species). Literature used: Jeannel (1941-1942), Lindroth (1974), Vázquez (1990), Campos (2003), Ortuño and Marcos (2003) and Peláez (2004).

Central grassland

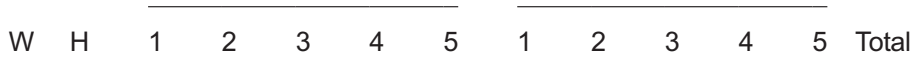

Amara (Amara) aenea (De Geer, 1774)

Amara (Bradytus) apricaria (Paykull, 1790)

Amara (Amara) eurynota (Panzer, 1796)

Amara (Amara) familiaris (Duftschmid, 1812)

Bembidion (Metallina) lampros (Herbst, 1784)

Bembidion (Emphanes) normannum Dejean, 1831

Bembidion (Phyla) tethys Netolitzky, 1926

Brachinus (Brachinoaptinus) bellicosus Dufour, 1820

Brachinus (Brachynidius) variventris Schaufuss, 1862

Calathus (Neocalathus) ambiguus (Paykull, 1790)

Calathus (Calathus) fuscipes graecus Dejean, 1831

Calathus (Neocalathus) granatensis Vuillefroy, 1866

Calathus (Neocalathus) mollis mollis (Marsham, 1802)

Calathus (Neocalathus) rotundicollis Dejean, 1828

Calosoma (Calosoma) inquisitor inquisitor

(Linnaeus, 1758)

Carabus (Oreocarabus) amplipennis getschmanni Lapouge, 1924

Carabus (Mesocarabus) lusitanicus complanatus Dejean, 1826

Carabus (Archicarabus) nemoralis prasinotinctus Heyden, 1880

Cicindela (Cicindela) campestris campestris

Linnaeus, 1758

Cryptophonus tenebrosus (Dejean, 1829)

Dinodes (Dinodes) dives kricheldorffi (Wagner, 1932)

Dixus sphaerocephalus (Olivier, 1795)

Graniger femoralis (Coquerel, 1858)

Harpalus (Harpalus) anxius (Duftschmid, 1812)

Harpalus (Harpalus) attenuatus Stephens, 1828

Harpalus (Harpalus) decipiens decipiens Dejean, 1829

Harpalus (Harpalus) distinguendus distinguendus

(Duftschmid, 1812)

Harpalus (Harpalus) ebeninus Heyden, 1870

Harpalus (Harpalus) honestus (Duftschmid, 1812)

Harpalus (Harpalus) neglectus neglectus

Audinet-Serville, 1821

Harpalus (Harpalus) oblitus patruelis Dejean, 1829

Harpalus (Harpalus) rufipalpis rufipalpis Sturm, 1818

Harpalus (Harpalus) serripes serripes (Quensel, 1806)

Masoreus wetterhallii wetterhallii (Gyllenhal, 1813)

Microlestes abeillei abeillei (Brisout de Barneville, 1885)

Microlestes corticalis (Dufour, 1820)

Microlestes negrita negrita Wollaston, 1854

Nebria (Nebria) salina Fairmaire \& Laboulbène, 1856

Notiophilus biguttatus (Fabricius, 1779)

Olisthopus elongatus Wollaston, 1854

Ophonus (Metophonus) brevicollis

(Audinet-Serville, 1821)

Ophonus (Hesperophonus) cribricollis (Dejean, 1829)

$\begin{array}{ccc}\mathrm{m} & \mathrm{O} & 1 \\ \mathrm{~m} & \mathrm{O} & 1 \\ \mathrm{~m} & \mathrm{O} & 1 \\ \mathrm{~m} & \mathrm{O} & 1 \\ \mathrm{D} & \mathrm{G} & 1 \\ \mathrm{~m} & \mathrm{O} & - \\ \mathrm{m} & \mathrm{G} & - \\ \mathrm{b} & \mathrm{O} & - \\ \mathrm{m} & \mathrm{O} & 1 \\ \mathrm{~m} & \mathrm{G} & - \\ \mathrm{b} & \mathrm{G} & 42 \\ \mathrm{D} & \mathrm{G} & - \\ \mathrm{D} & \mathrm{O} & 2 \\ \mathrm{D} & \mathrm{F} & -\end{array}$

m F

b

b $F$

b G

$\mathrm{m}$

m G

b

$\mathrm{m}$

$\mathrm{m}$

$m$ G - 23

4

$-$

$-$

$-$

$-$

$8 \quad 1$

$-$

- 12

9194

-

9
-
-
1
-
-
-
-
-
8
6
-
-

$\begin{array}{ll}7 & 4 \\ - & - \\ - & 2 \\ - & 2 \\ - & - \\ - & - \\ - & 2 \\ - & - \\ - & - \\ - & - \\ 78 & 59 \\ - & 29 \\ 1 & 16 \\ - & 18\end{array}$

4
-
2
2
-
-
2
-
-
-
59
29
16
18

$\begin{array}{rlll}- & 1 & 1 & 30\end{array}$

- $-\quad-\quad-\quad 1$

- $-\quad-\quad-3$

$-1-5$

- $\quad-\quad-\quad-1$

$1--$

- $\quad$ - $\quad$ - $\quad$ - 11

$1 \quad-\quad-12$

- $\quad-\quad-\quad-\quad 2$

- $\quad-\quad-30$

$\begin{array}{lllll}27 & 200 & 286 & 150 & 1,071\end{array}$

$\begin{array}{lllll}37 & 22 & 61 & 20 & 169\end{array}$

$\begin{array}{lllll}5 & 6 & 5 & 1 & 43\end{array}$

$43 \quad-\quad 34 \quad 3 \quad 98$

$\begin{array}{lllll}4 & 20 & - & - & 4\end{array}$

$\begin{array}{llllll}22 & 17 & 1 & 6 & 12 & 59\end{array}$

$\begin{array}{llllll}2 & 5 & 3 & 1 & 3 & 14\end{array}$

$m \quad$ G $266 \quad 62 \quad 50 \quad 49 \quad 159 \quad 3 \quad-\quad \begin{array}{llllll}19 & 4 & -612\end{array}$

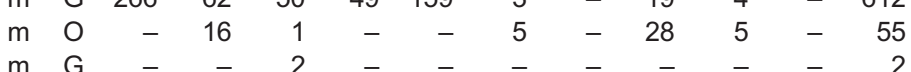

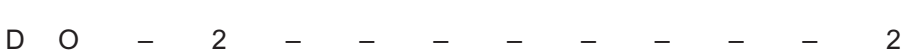

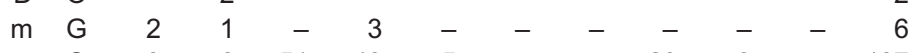

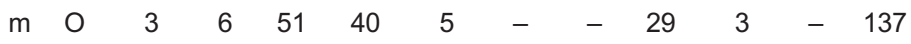

$\mathrm{m} \mathrm{G} \quad-\begin{array}{rllllllll} & 30 & 3 & 31 & - & 2 & - & 3 & -\end{array}$

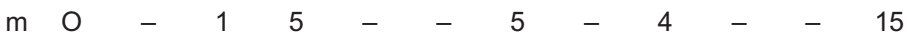

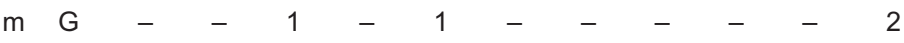

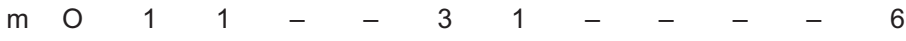

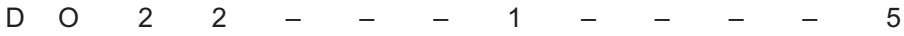

$\begin{array}{lllllllllllll}\mathrm{m} & \mathrm{O} & 2 & 2 & 8 & 5 & 3 & 7 & 19 & 1 & 48 & 4 & 99\end{array}$

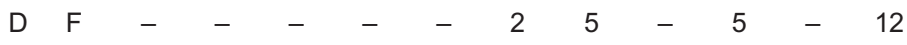

$\begin{array}{lllllllllllllll}\mathrm{m} & \mathrm{O} & 1 & 1 & 1 & 1 & 1 & - & - & - & - & - & 5\end{array}$

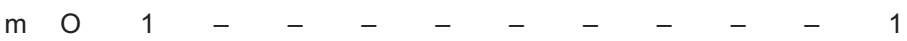

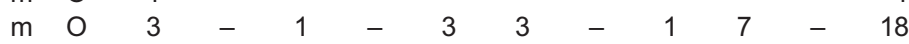


Ophonus (Metophonus) parallelus (Dejean, 1829)

Poecilus (Coelipus) crenulatus crenulatus

(Dejean, 1828)

Poecilus (Macropoecilus) kugelanni (Panzer, 1797)

Poecilus (Poecilus) versicolor (Sturm, 1824)

Pseudomasoreus canigoulensis (Fairmaire \& Laboulbène, 1854)

Pseudoophonus (Pseudoophonus) rufipes (DeGeer, 1774)

Steropus (Steropidius) gallega (Fairmaire, 1859)

Steropus (Sterocorax) globosus ebenus (Quensel, 1806)

Syntomus foveatus (Geoffroy, 1785)

Synuchus vivalis vivalis (Illiger, 1798)

Trechus (Trechus) obtusus asturicus Jeannel, 1921

Trechus (Trechus) quadristriatus (Schrank, 1781)

Zabrus (Iberozabrus) silphoides asturiensis

Heyden, 1880

Number of individuals

Number of species

Rarefied number of species

$\begin{array}{rrrrrrrrrrrrrr}\mathrm{m} & \mathrm{O} & - & 1 & - & - & - & - & - & - & - & - & 1 \\ \mathrm{~m} & \mathrm{O} & - & - & - & 3 & - & - & - & - & - & - & 3 \\ \mathrm{~m} & \mathrm{O} & 1 & - & 14 & 6 & 7 & 23 & 19 & 116 & 9 & 35 & 230 \\ \mathrm{~m} & \mathrm{O} & 1 & 2 & - & - & - & - & - & - & - & - & 3 \\ & & & & & & & & & & & & \\ \mathrm{~m} & \mathrm{~F} & - & - & - & - & - & - & 1 & - & - & - & 1 \\ & & & & & & & & & & & & \\ \mathrm{~m} & \mathrm{O} & - & - & - & - & - & - & - & - & 1 & - & 1 \\ \mathrm{~b} & \mathrm{G} & - & - & 2 & 2 & 7 & - & 17 & 7 & 32 & 11 & 78 \\ & & & & & & & & & & & & \\ \mathrm{~b} & \mathrm{G} & 8 & 92 & 77 & 18 & 71 & 60 & 28 & 269 & 54 & 92 & 769 \\ \mathrm{~b} & \mathrm{G} & 68 & 53 & 7 & 14 & 4 & 5 & - & 3 & - & 3 & 157 \\ \mathrm{~m} & \mathrm{G} & - & - & - & 1 & - & 3 & - & - & - & 4 & 8 \\ \mathrm{D} & \mathrm{G} & 11 & 8 & - & - & 4 & 41 & 26 & 22 & 7 & 2 & 121 \\ \mathrm{~m} & \mathrm{G} & - & - & 2 & 7 & - & 41 & 36 & 14 & 31 & 4 & 135 \\ & & & & & & & & & & & & \\ \mathrm{~b} & \mathrm{O} & 29 & 33 & 10 & 2 & 9 & 3 & - & 18 & 1 & - & 105 \\ & & & & & & & & & & & & \\ & 456 & 379 & 459 & 284 & 366 & 378 & 313 & 776 & 605 & 358 & 4,374 \\ & & 28 & 26 & 23 & 21 & 18 & 29 & 18 & 22 & 24 & 18 & 55 \\ & 18 & 21 & 18 & 19 & 16 & 26 & 17 & 16 & 18 & 16 & \end{array}$

